Japanese in Yezo, which, making the usual allowance for official exaggeration in matters of this kind, must probably be reduced to about 80,000 . Be this as it may, it is certain that the fertile island of Yezo, which is appreciated in a certain way by the Japanese, but which is very irrationally and imperfectly utilized, is very thinly populated. The island has an area of nearly 80,000 $\square$ kilometres, and a population of only about two to the square kilometre.

The Ainos - whose unsophisticated artlessness, love of truth, peaceful disposition, hospitality, and discreet, modest, and sober deportment, by contrast with other orientals, strike one all the more agreeably - show, in their short but well-proportioned body, thick and beautiful hair, and physiognomy, particularly in the deep-set eyes, unmistakable agreements with people of more western countries, say, central Asia. In language, as well as customs and traditions, they are decidedly strangers to the Japanese; but, so peaceful are they, they submit freely to the yoke that has been placed upon them, without ever plotting mischief. Whether for them, as well as for the rich natural advantages of the island of Yezo, a colonization in European fashion would be a great benefit in comparison with that of the Japanese, who have much to learn and much to do for a long time to come in their own country, may here be left undecided. However, such a wish will certainly appear natural to all those who have gained a more intimate acquaintance with the island of Yezo and its inhabitants.

\section{INFLUENCE OF THE VAGUS NERVE UPON THE HEART.}

Is continuation of his studies upon the physiology of the frog's heart, Löwit confirms ${ }^{1}$ Gaskell's discovery, that in normal diastole the cardiac muscle is not completely relaxed, but in a state of slight tonic contraction: this, Löwit finds, is abolished during vagus inhibition. The powerful beats which usually follow a period of inhibition must be due to some change in the heart-muscle, and not in its motornerve centres; for Kronecker has proved that every cardiac contraction is maximal. Their cause Löwit finds in the more complete diastolic expansion; and he also explains similarly the more vigorous pulsations sometimes seen during a vagus stimulation not powerful enough to alter the heart's rate of beat. He confirms . Schiff's usually ignored discovery, that stimulating the pneumogastric sometimes quickens the pulse; but, after a careful study of the circumstances under which this phenomenon occurs, he rejects Schiff's hypothesis, that the vagus contains only one set of heart nerve-fibres, whose action varies with degree of stimulation, etc. We must assume two distinct sets of fibres, - a cardio-accelerator and a cardio-inhibitory: the latter are more irritable, but more easily injured, bearing thus the same relationship to the accelerator fibres as do the vaso-constrictory nerves to the vaso-dilator, according to Goltz. By exposing the frog's vagus to the action of substances, as nitre, which are known to diminish nerve irritability, one can turn the vagus into a pulsequickening nerve: on washing out the nitre, it again becomes pulse-slowing; and so, back and forth, several times, until death-changes commence. In mammalia the phenomenon cannot be reproduced with the same certainty; but occasionally one can succeed in getting the vagus into a condition in which its inhibitory fibres are not irritable, while the accelerator are. During vagus acceleration the frog's ventricle becomes paler, indicating a contracted condition of its musculature even in diastole. This abnormal state of tonic contraction is not the cause of the acceleration, for the pallor may precede the pulse-quickening, or last after it; and weak stimuli sometimes cause acceleration with no pallor. The small pulsations usually seen during the acceleration are due to the increased tonicity of the heartmuscle usually present at the same time, and preventing diastolic relaxation of normal extent. The accelerator fibres probably act on motor-nerve centres in the heart, arousing processes, which, when feeble, merely alter the rate of beat; when more powerful, also increase the tonus of the heart-muscle.

H. Newell Martin.

\section{THE EXTINCT LAKE AGASSIZ.}

Is the recently published Tenth annual report of the geological and natural-history survey of Minnesota, for 1881, Prof. N. H. Winchell gives an abstract (p. 5) of Mr. Warren Upham's observations on the shore-lines of the great sheet of water that once flooded the valley of the Red River of the North, and overflowed southward into the Minnesota. "The lake had three stationary periods, forming three beaches. They all ascend above a given datum level toward the north, the rate increasing in going toward the north. The highest beach-line ascends 125 feet in about 150 miles, the beach being one continuous shore-line. The northern portion of the lake fell at intervals from this high beach-line, . . . while the water-level in the extreme southern part stood nearly stationary, the northern fractional beaches converging into one toward the southern extremity of the lake. The next distinct beach, found in the southern part of the region, ascends toward the north 70 feet in 150 miles. ... The fall of the lake had therefore been sixty feet more at the northern than at the southern end. ... The third beach-line, formed when the outlet had been excavated to the level of Lake Traverse, is known along a distance of 135 miles; and its northward ascent was at first 50 feet, and afterwards only about 25 feet. . . . The fall of Lake Agassiz from the highest beach level to the third at Lake Traverse was about 80 feet, and, in the vicinity of Maple Lake, 165 feet. . . These phenomena seem inconsistent with that hypothesis which supposes an elevation of northern land as a barrier to contain this vast inland lake, inasmuch as these beaches would have to present a slope in the opposite direction, in order to change the outlet from Lake Traverse to Hudson's Bay. . . . They have been ascribed to the operation of the glacial period in the epoch of its decline, when the ice still existed toward the north as a barrier to prevent northern drainage; . . . and in the opinion of Mr. Upham, its attraction was sufficient to move the mass of water toward itself, and to cause an ascending shore-line in that direction. . . . Lake Agassiz probably covered Red Lake under 50 or 100 feet of water above its present level, Lake of the Woods under about 200 feet, the Red River Valley at St. Vincent 450 feet, and Lake Winnipeg about 600 feet." The area thus flooded is much larger than heretofore supposed.

\section{LETTERS TO THE EDITOR.}

Movement of the arms in walking.

IT seems to me I can best lay this ghost of our animal origin by drawing attention to the fact that the swinging of any part that is sufficiently free may be 
used for steadying the body in walking. In man the arms are used, because most movable; but in lower animals the head is most often used. The domestic fowl moves the head back and forth alternately with the movement of the legs; the horse moves the head up and down; the cow moves the nose back and forth.

Are these movements ghosts of a former real walking with the head?

Berkeley, Cal., March 7, 1883.

\section{Suggested improvement in lighthouses.}

The articles in Scrence during March, on the use of the electric light in lighthouses, recalls what I think is a most useful improvement suggested, or at least advocated, by an English yachtsman,-Mr. R. F. McMullen, - in a little book called the 'Voyage of the Orion.' In the vicinity of a powerful lighthouse, whether lighted by electricity or otherwise, the great glare of the light completely blinds the eye of the navigator. To remedy this, Mr. McMullen proposes that a colored shade should be fixed so as to change the color of, and diminish, the light within a fixed radius of from one to three miles, according to circumstances. Thus, besides the protection given the eye from too much glare within the radius of the shade, the navigator would also be warned that he was within a known distance of the light, - a consideration which would often be of much value.

I sincerely hope that our Lighthouse board may make some experimental trials of this plan, as well as turn its attention to the adoption of flashing lights, instead of revolving lights with long periods of darkness. Indeed, in our whole system of lights, and also of buoys and other 'day-marks,' we are behind the times.

Boston society of natural history, March 12, 1883 .

Fluidal cavities in quartz-grains of sandstones.

It is interesting to note that the minute cavities containing a liquid and moving bubble, so common in the quartz of granite rocks, are also to be found in sandstones. This is especially the case with a hard, compact Potsdam sandstone quarried at Fort Ann, Washington county, N.Y. The cavities, though very minute, are abundant, and the included bubble very sensitive, being in a constant state of rapid movement.

G. P. MERRILL.

$$
\text { U.S. national museum. }
$$

The copper-bearing rocks of Iake Superior.

In ScIEnce, No. 5, Professor Irving takes issue with my statement that there is no evidence whatever of the Lake Superior copper rocks holding any other place in the geological series than that which includes Potsdam and primordial Silurian or lower Cambrian.

In making the statement, I referred only to those parts of the north shore, extending from Sault St. Mary to Thunder Bay, which I have myself examined.

I could not presume to discuss, much less to dispute, the evidence which Professor Irving adduces, in disproof of my statement, from the St. Croix region and the south shore, neither of which I have ever seen; but I may be permitted to say, that the unconformities mentioned by Professor Irving, and which I have no doubt are real, do not, in my opinion, in the least invalidate my statement. Unconformities, even if locally very great, are not necessarily any indication of a great time-gap. And it seems to me that too much importance has been attached to these by Professor Irving, and far too little to the immense difference in the physical condition of the groups he now correlates; viz., the original Huronian of the north shore of Lake Huron, and Hunt's Animikie group, lower Cambrian of Thunder Bay, or, to come closer, the cleaved roofing-slates of Thompson in Minnesota, and the horizontal micaceous argillites, black dolomites, and cherty rocks, of Pie Island, McKay's Mountain, Thunder Cape, etc.

In Canada, at least, these two formations are absolutely and undoubtedly distinct, physically, mineralogically, and geologically; while the latter, as seen around Thunder Bay, is followed in almost conformable sequence by the red and white quartzose sandstones, conglomerates, amygdaloids, etc., of the socalled upper copper-bearing or Keweenian series of Hunt. These I have examined from Thunder Bay, around the north shore to Gros Cap, where they rest directly on the Laurentian gneiss, the Animikie group and the underlying Huronian being wanting. A short distance to the east, however, the latter appears in full force, but overlaid neither by Animikie nor by Keweenian (i.e., lower Cambrian), but by the Sault St. Mary sandstones, which, in view of their relation to the Black River limestone above them, and to the Keweenian in Gonlais and. Bachewarmg Bays, are much more probably representative of the horizon of the St. Peters sandstone, or Chazy and calciferous, than of the St. Croix Potsdam. The respective limits of the two sandstones on the south shore seem uncertain.

The arrangement above indicated brings the whole succession of the Lake Superior, Cambrian, and Cambro-Silurian formations into perfect accord with that of the same formations in the Appalachian region, where, as I have elsewhere stated, indications of local contemporaneous volcanic action are not wanting at about the same horizon - lower Cambrian and upper Huronian - as that at which they occur in the Lake Superior region; the chief difference being, that the formations in the former region are folded and metamorphosed almost past recognition, and in the latter not more so than are many similar rocks of cretaceous and tertiary age.

I think, if Professor Irving could visit Michipicoton Island, he would be able to recognize plenty of volcanic detrital matter or tuffs among the copperbearing rocks. The vast areas over which I have examined the ejectamenta of the extinct tertiary volcanoes of Australia enables me very readily to recognize such rocks when seen; but their occurrence at Michipicoton, and elsewhere on the north shore, is no proof that they also occur to the south, and therefore I fail to see why Professor Irving should dissent from my statement on this point.

\section{ALFRED R. C. SELWYN,} Director Geol. and nat. hist. surv. of Canada. Ottawa, March 14, 1883.

\section{Snow-drifts.}

Having often noticed the drifting of snow in parallel lines over the ice on our lakes, this explanation has suggested itself. Very often, when the wind drives the snow against any object, as a tree or fencepost, the snow will be hollowed out on the side toward the wind, and heaped up on the other side. This is explained by the fact that the tree acts as a reflecting surface, creating a counter-current of air, and preventing the accumulation of snow on the side toward the wind.

Might not the parallel ridges of snow on ice be explained in the same way? The first deposit of snow is caused by the flakes catching on some inequality or damp spot on the ice. This deposit acts as a re- 